Ewa Manikowska*

emaniko@poczta.ispan.pl

orcid.org/0000-0001-6633-823X

Institute of Art, Polish Academy of Sciences

ul. Długa 28

00-238 Warsaw, Poland

\title{
Museums and the Traps of Social Media: The Case of the Auschwitz-Birkenau Memorial and Museum
}

\begin{abstract}
In this article I discuss both the recent threats as well as opportunities posed by social media to the activities of museums, taking into account social media's importance as an evolving space of both social outreach and social activism. Recalling the controversies around the U.S. and UK museums' social media responses to George Floyd's death, I argue that museums run the risk of politicization and entanglement in controversial issues which are not necessarily linked to their profile and mission. I analyse museums' social media guidelines, good practices, and mission statements, and posit that they play a fundamental role in integrating the new realm of the Web 2.0 into traditional museum activities. My main case study and example of good practice is the Auschwitz-Birkenau
\end{abstract}

\footnotetext{
* Ewa Manikowska serves as an Associate Professor at the Institute of Art of the Polish Academy of Sciences in Warsaw (Poland). She holds a European Doctorate in the Social History of Europe and the Mediterranean (University of Warsaw/Ca' Foscari University of Venice). Prof. Manikowska has also worked for various museum institutions, including Galleria Palatina in Palazzo Pitti in Florence (Italy) and the National Museum in Warsaw. Her research interests focus on the history of collecting, survey photography, cultural heritage, and art restitution at the time of the First World War. Currently, she acts as Principal Investigator of the Polish research team of the EU-funded Project "Digital Heritage in Cultural Conflicts DigiCONFLICT" (https://digiconflict.net). Prof. Manikowska is also a guest editor of this issue of "Santander Art and Culture Law Review". She is the author of the book Photography and Cultural Heritage in the Age of Nationalisms: Europe's Eastern Borderlands (1867-1945), published by Bloomsbury in 2019.

This article was prepared within the framework of the research project "Digital Heritage in Cultural Conflicts", supported by the Ministry of Culture and National Heritage under the JPICH Digital Heritage programme - support for scientific research on cultural heritage under the Joint Programming Initiative on Cultural Heritage (JPICH), No. 98/DSAP-JG/2018.
} 


\title{
GENERAL ARTICLES
}

Ewa Manikowska

\begin{abstract}
Memorial and Museum. It has constantly embedded general ethical and educational principles and guidelines of Holocaust commemoration and education into its more than 60-years' experience in dealing with and taming political and cultural controversies surrounding this memory site of universal importance, and this embeddedness lies at the core of its social media activity. Defined as an "online community of remembrance", it consists of well-thought-out initiatives which aim at informing the public about the everyday history of the camp, involving itself in the current commemorations and anniversaries, and rectifying simplifications and misinformation about Auschwitz and the Holocaust. I also analyse the fundamental role played by the official social media profiles in managing the crisis which arose at the beginning of 2018 with the amendment of the socalled "Holocaust Law" in Poland.
\end{abstract}

Keywords: museums, social media, museum education, museum ethics, Holocaust commemoration, social activism

\section{Introduction}

For at least the last decade, the operation of institutional social media profiles has become a must in the activity of both major and minor museums worldwide. Generally considered as important instruments of promotion and education, a democratizing space of public participation and communication, and a tool of outreach on a boundless global scale, social media activities are seen as a natural extension of museums' activities. Moreover, the number and variety of social media profiles and their outreach are recognized as an indicator of a given institution's relevance and a measure of its success. Social media is at the forefront of museums' responses to the digital age. Social media activities are managed by new departments, which have been established in the last dozen years, usually containing the word 'digital' in their name (Digital Department, Digital Engagement, Digital Media, Digital Experience, etc.) and run by professionals with an IT, marketing, gaming, or social media background.

Much has been written about the opportunities offered by the expansion of social media in museums, in particular springing from their mass and un-hierarchical nature. ${ }^{1}$ This article however focuses on the threats accompanying museums'

1 See, for example, R. R. Janes, R. Sandell (eds.), Museum Activism, Routledge, London 2019; A. Russo et al., Participatory Communication via Social Media, "Curator. The Museum Journal" 2008, Vol. 51, pp. 21-31; A. Wong, Social Media Towards Social Change: Potential and Challenges for Museums, in: R. Sandell, E. Nightingale (eds.), Museums Equality and Social Justice, Routledge, London 2012, pp. 281-293; R.H. Baggesen, Augmenting the Agora: Media and Civic Engagement in Museums, "MediaKultur: Journal of Media and Commu- 
engagement in this new communication realm. While social media, and in particular Twitter, have become in the most recent years an important and evolving space of social activism and protests (on the local, national, and global levels), museums run the risk of politicization and entanglement in controversial issues which are not necessarily linked to their profile and mission. The protests against police brutality, social injustice, and racism, which sprang out in the U.S. in 2012, are considered as a model example of a social media movement. Its name comes from the hashtag \#BlackLivesMatter, which according to the survey of the Pew Research Centre was used nearly 30 million times on Twitter up till May 2018. ${ }^{2}$ Since 2012 this hashtag has appeared consistently on social media and its use increases in response to specific events. As the research has shown, the hashtag is used in reference to six main, highly politicized and controversial topics: fatal encounters between the police and black men and women; violent acts in general; police and law enforcement policies; national politicians and political parties; race-related incidents; and protests. ${ }^{3}$ The survey did not cover the recent social media response to the death of George Floyd, which is analysed in this article with respect to museums' social media activities. Thus this article takes into account the risks associated with the involvement of museums in contemporary social events and confronts such involvement with museums' social media best practices and guidelines to see how they are implemented in practice. It is argued that the main problem of museums' social media activity is their vague and usually non-specified links with the museums' mission.

The main case study of this article is the Auschwitz-Birkenau Memorial and Museum ("the Museum"), an institution which from the time of its foundation in 1947 has had to deal with the claptraps of political and social involvement, on both on the national and global scale. Since 2011 the Museum has been active on social media, exploiting the Web 2.0 to pursue its educational mission. In recent years the Museum's Twitter account has gained a large and consistently-growing global following and interest, which in turn has increased its impact and authority. The Museum's social media campaigns and posts are resonating not only in cyberspace, but are also widely described and commented on in international media outlets and often considered a voice of authority with respect to Holocaust history, education, and the problems surrounding Holocaust denial. This article will demonstrate that the Museum's many years' experience in dealing with and taming the political, social, and cultural controversies surrounding the heritage of Auschwitz, and its thoughtout and consistent mission lies at the basis of its successful and influential social media policy.

nication Research" 2014, Vol. 30, pp. 117-131; N. Mandarano, Musei e media digitali [Museums and Digital Media], Carocci Editore, Roma 2019.

2 M. Anderson et al., Activism in the Social Media Age, 11 July 2018, https://www.pewresearch.org/internet/2018/07/11/activism-in-the-social-media-age/ [accessed: 10.09.2020].

3 Ibidem, p. 3. 


\section{GENERAL ARTICLES}

Ewa Manikowska

\section{Museums, Social Media, and Activism}

In view of the recent protests following George Floyd's death, sometimes considered as the largest movement in the history of the United States, many museums, in particular American and British ones, have made official statements of support for the Black Lives Matter (BLM) postulates of justice and racial equality. ${ }^{4}$ They were posted immediately on the institutions' social media profiles, and took the form typical for the genre: brief notices, hashtags, emojis, images of works of art referring to police brutality or racism, etc. Museums willingly joined wider online campaigns, like the Blackout Tuesday Instagram initiative of posting a blank black square as the only post for the day. ${ }^{5}$ Moreover, the museums' social media activities were quickly amended and adjusted to fit the expectations of the on-line community, which widely criticized the superficiality of some of the posts and the alleged lack of engagement. The Getty Museum, for example, was strongly criticized for not making any direct reference to Floyd's murder, police brutality, and racism in its social media post of 31 May 2020. ${ }^{6}$ In face of the massive criticism on the following day, James Cuno, President of the J. Paul Getty Trust, issued an apology and a statement making clear references to the current events and announcing the Getty's adherence to the Blackout Tuesday initiative. This statement, preceded by a typical element of the genre of social media posts - a direct response to and discussion of the on-line criticism ("We heard you. Thank you. We learned that we can do much better expressing our Getty values than we did yesterday, and we apologize") - was of course posted on the Getty's social media profiles.

The immediate - usually roughly thought-out, superficial and simplified in their nature institutional social media posts referring to the George Floyd protests and to the BLM movement - provoked a serious and public crisis of confidence towards museums on the part of their employees, professionals, and of the larger society. In just a few weeks from their first engaged posts, many museums had to face accusations of discrimination and white supremacy in their employment and exhibition policies. ${ }^{7}$ In addition, in the UK the social media support for the BLM postulates

\footnotetext{
4 A. Reynolds, Circulation, Impact and the Use of Twitter in Contemporary Museum Activism, "Participations, Journal of Audience \& Reception Studies" 2020, Vol. 17, pp. 126-146; M. Charr, How Have Museums Responded to the Black Live Matters Protests?, "MuseumNext", 20 June 2020, https://www.museumnext.com/ article/how-have-museums-responded-to-the-black-lives-matter-protests/ [accessed: 10.09.2020].

5 A collective protest launched by the music industry and joined by many other private and public institutions, with the idea of suspending activity among others in social media on 2 June 2020. See A. Shaw, G. Harris, Art World Presses Pause for \#BlackOutTuesday, "The Art Newspaper", 2 June 2020, https://www. theartnewspaper.com/news/art-world-presses-pause-for-blackouttuesday [accessed: 20.08.2020].

6 A. Greenberger, T. Solomon, Major U.S. Museums Criticized for Responses to Ongoing George Floyd Protests, "ArtNews", 2 June 2020, https://www.artnews.com/art-news/news/museums-controversy- george-floydprotests-1202689494/ [accessed: 10.09.2020].

7 See, for example, G. Harris, 'Racist' Gallery in Liverpool Museum to be Overhauled in Light of Black Lives Matters, "The Art Newspaper", 13 July 2020, https://www.theartnewspaper.com/news/racist-liverpool-
} 
was promptly associated with the controversial and hot-button issue of the decolonization of museums' collections. The British Museum in particular was accused of hypocrisy after the posting on its official Twitter account the Director's (Hartwig Fischer's) statement of solidarity with the Black community throughout the world. The on-line community (including top intellectuals, scholars, and museum professionals) in more than 1,000 responses to the post evoked the British Museum's reluctance to confront with the issue of colonial heritage from Africa in its holdings. ${ }^{8}$ Needless to say, social media once again became a major space on which the newly-arising controversies were played out and confronted. Dan Hicks, curator of World Archaeology at the Pitt Rivers Museum and ardent advocate of the restitution of colonial collections," besides posting his own comment ("The British Museum is white infrastructure") decided to archive all the voices of critique addressed to the British Museum under the explicit Twitter handle @BrutishMuseum. ${ }^{10}$

Tellingly, even directors of major museum institutions - such as James Cuno and the above-mentioned Hartwig Fischer, and established scholars and museum professionals such as Dan Hicks - have decided to use social media to discuss and to make their points with respect to such complex and controversial issues as, inter alia, restitution, exhibition, and employment policies. Moreover, they consequently made use of official social media profiles to comment and make statements on general political, social, and cultural controversies and issues with no direct links to the mission, activity, and profile of the given museum. Indeed, the authority of the museum leader, established scholar, and curator legitimized the reduction of the discussion about controversial, complex, and multifaceted issues to images, hashtags, emojis, and short messages (with their attendant word count restrictions). Moreover, in the fervour of the moment, even the most established institutions and professionals committed elementary mistakes. The Metropolitan Museum of Art ("the Met") and the San Francisco Museum of Modern Art, for example, were forced to apologize to the American conceptual artist Glenn Ligon for the unauthorized use of one of his works to illustrate its statement of support for the BLM movement on social media. ${ }^{11}$ Keith Christiansen, the established chairman of European Painting at the Met, had to apologize for a post on his private Instagram pro-

museum-gallery-to-be-reconfigured-in-light-of-black-lives-matter [accessed: 20.09.2020]; A. Randle, We Were Tired of Asking: Why Open Letters Have Become Many Activists' Tool of Choice for Exposing Racism at Museums, "ArtNet News", 15 July 2020, https://news.artnet.com/art-world/museum-open-letters-activism-1894150 / [accessed: 20.09.2020].

8 K. Brown, 'This Is Performative': Critics Mercilessly Mock the British Museum for Its 'Hollow' Statement of Solidarity with the Black Live Matter Movement, "Artnet News", 9 June 2020, https://news.artnet.com/art-world/ british-museum-black-lives-matter-1882296 [accessed: 20.09.2020].

9 D. Hicks, The Brutish Museum. The Benin Bronzes, Colonial Violence and Cultural Restitution, Pluto Press, London 2020 [forthcoming].

10 K. Brown, op. cit.

11 A. Greenberger, T. Solomon, op. cit. 


\section{GENERAL ARTICLES}

Ewa Manikowska

file in which he made a symbolic connection between the present-day destruction or removal of monuments and memorials associated with white supremacy, racism, and colonialism with Alexandre Lenoire's salvage of medieval monuments at the time of the French Revolution. In fact, a post built on a subtle and symbolic association of present-day events with a cultural phenomenon of the past was - given the Met's supposedly "hollow" social-media involvement in the BLM movement - read by many as an expression of "white supremacy" and a striking example of the museum's hypocrisy.

\section{Social Media Guidelines and Codes of Conduct: The Case of the Smithsonian Institution}

Indeed, the issues of copyrights and personal social media accounts of museums' employees are covered in the social media best practices adopted by museums. Such documents, usually rudimentary and short, follow the general outline of the guidelines for a successful social media policy in any company or institution ${ }^{12}$ and, sometimes, touch upon issues specific for the museum sector. One of the most elaborate, earliest, and model documents of this kind is the 2011 Smithsonian Institution's (SI) directive on the Management of Official Smithsonian Social Media Accounts. ${ }^{13}$ Social media began to proliferate at the $\mathrm{SI}$ in response to the challenges and opportunities of the Web 2.0. The plan to introduce social media was elaborated during an innovative public meeting process, which included workshops, YouTube, Twitter, and public wiki contests as well as the conference 2.0: A Gathering to Re-Imagine the Smithsonian in the Digital Age, a brain-storm meeting between web and digital experts with the Sl's staff. ${ }^{14}$ Moreover, social media was only one among the many elements of the larger Sl's Information Technology Plan 2010-2015, which provided for a wider use of technology to respond to the challenges and grasp the opportunities of the 21 st century ${ }^{15}$ In this document, social media appeared in the description of three among six strategic priorities underlying the IT goals of the SI: broadening access (the role of social networking in broadening access globally and in bringing the public, scholars, and educators together); crossing boundaries (social media as an important virtual collaboration environment); and revitalizing education (social media along with gaming and mobile devices recog-

12 N. Flynn, The Social Media Handbook. Rules, Policies and Best Practices to Successfully Manage Your Organization's Social Media Presence, Posts and Potential, John Wiley \& Sons, Hoboken 2012.

13 Smithsonian Institution, Smithsonian Directive 814: Management of Official Smithsonian Social Media Accounts, 27 June 2019, https://www.si.edu/content/pdf/about/sd/SD-814.pdf [accessed: 10.09.2020].

14 M. Edson, Fast, Open and Transparent. Developing the Smithsonian's Web and New Media Strategy, in: J. Trant, D. Bearman (eds.), Museums and the Web 2010: Proceedings, Archives \& Museum Informatics, Toronto 2010, https://www.museumsandtheweb.com/mw2010/papers/edson/edson.html [accessed: 10.09.2020]. 
nized as important channels for crossing the lines between formal and informal education). Importantly, the new IT strategies and plans were from the start connected to the Sl's founding mission of 1846 - the increase and diffusion of knowledge specified in 2010 as consisting of four grand challenges: unlocking the mysteries of the universe; understanding and sustaining a biodiverse planet; valuing world cultures; and understanding the American experience. ${ }^{16}$ Such challenges were to be dealt with by the SI through using all of the potential of its various institutions, which should complement each other under the heading of "One Smithsonian".

According to the Information Technology Plan 2010-2015, if information technologies were properly applied they could play a pivotal role in achieving the Sl's mission. This was one of the main issues of enquiry of an audit commissioned by the SI in 2010, after two years of its involvement with social media, to assess the plans for and current uses of social media, to check whether they are productive, responsible, and complying with the Sl's mission. ${ }^{17}$ The audit named social media as an important tool for achieving one of the seven priorities of Sl's strategic plan for the years 2010-2015 (essentially repeated in the following 2017-2022 plan), ${ }^{18}$ namely the broadening of access to Sl's collections. ${ }^{19}$ It pointed out that social media were and should be used for education (diffusion of knowledge and for providing access to Sl's resources and collections). Given the complex and varied structure of SI (19 museums and galleries, a zoological park, and a research and educational centre) and its number of social media profiles at the time of the audit (342), the links between the posted content and SI's mission were, of course, varied, and included notifications of events, descriptions of objects, explanations of historical facts, and links to multimedia. ${ }^{20}$ Stressing the need for Sl's visible presence on social media, the audit paid particular attention to the successful efforts of engaging in a dialogue with virtual audiences, i.e. adapting its educational, informational, or scientific goals to the non-hierarchical and interactive nature of the Web 2.0. This issue is one of the main goals of the Sl's strategic plan for the years 2017-2022, defined as "understanding and impacting 21st-century audiences". ${ }^{21}$

The SI social media directive was issued following the implementation of the audit's recommendations. It explained in detail the new management and structure of the SI social media models and introduced a social media policy. Repeating the

\footnotetext{
16 Smithsonian Institution, Strategic Plan: Fiscal Years 2010-2015. Inspiring Generations through Knowledge and Discovery, p. 4, https://files.eric.ed.gov/fulltext/ED583517.pdf [accessed: 10.09.2020].

17 Smithsonian Institution, Office of the Inspector General, Use of Social Media: Report Number A-11-01, 28 September 2011, https://www.si.edu/Content/OIG/Audits/2011/A-11-01.pdf [accessed: 10.09.2020].

18 Smithsonian Institution, Strategic Plan: Smithsonian 2022, https://files.eric.ed.gov/fulltext/ED583523. pdf [accessed: 10.09.2020].

19 Smithsonian Institution, Strategic Plan: Fiscal Years 2010-2015. Goal 3 of the 2022 SI strategic plan provides for a yearly outreach to one billion people in its digital first strategy.

20 Ibidem, p. 4.

21 Smithsonian Institution, Strategic Plan: Smithsonian 2022, p. 6.
} 


\section{GENERAL ARTICLES}

Ewa Manikowska

general assumptions of social media best practices for a company or institution, the directive places much stress on the prevention of their unlawful use. It enumerates the typical categories of prohibited posts (offensive, partisan, discriminatory, personal, etc.) and imposes a comment policy. It refers to the Social Media Handbook, a manual for internal use only and issued in parallel with the directive, to provide examples of unlawful posts. Referring to the distinctiveness of a memory institution, the directive prohibits in particular the posting of content unrelated to Sl's mission, placing this category as first in the enumeration of unlawful content. Among other things, it also places much stress on the copyrights of the posted content - the directive refers to the SI directive on Digital Asset Access and $\mathrm{Use}^{22}$ and requires that permission be obtained for content that the SI does not own, does not have permission to use, or is not in the public domain.

The SI directive and the Social Media Handbook together form one of the most elaborate museum documents of its kind. Importantly, they are strictly connected to other directives, codes of conduct, policy documents, and mission statements adopted by the SI. The social media guidelines or codes of conduct of many museums, if they have them at all, are usually much more concise and general. The British Museum, for example, adopted in 2016 a short code of conduct addressed to its social media users, together with an explanation of its content policy. ${ }^{23}$ The Getty Museum follows the general standards established in the J. Paul Getty Trust's social media policy document, ${ }^{24}$ which, among other provisions, briefly explains who and how one can open a Getty social media account. It calls for adherence to the Getty brand standards, comments on the restrictions imposed on private social media accounts of the staff, and explains how to interact with the audience. With respect to intellectual property issues, the handling of the posts of disruptive users, and issues of advocacy and political engagement of a post, it refers to other guidelines adopted by the Getty. Still, what arguably distinguishes SI's social media practice is not only the elaborate nature of its guidelines, but the clear connection with the Institution's well-thought-out and constantly updated mission and strategic plan, which since the rise of social media and the proliferation of IT takes into consideration the impacts, opportunities, and threats of social media use.

At the time of the George Floyd protests, the SI had already been involved for at least four years in museum, research, and educational programmes focused on sensitizing and educating staff about issues at the heart of the BLM movement.

22 Smithsonian Institution, Smithsonian Directive 609: Digital Asset Access and Use, 19 December 2019, https://www.si.edu/content/pdf/about/sd/SD609.pdf [accessed: 10.09.2020].

23 British Museum, Social Media Code of Conduct, https://www.britishmuseum.org/terms-use/social-media-code-conduct [accessed: 10.09.2020]. 
In 2016 it inaugurated a new institution - the National Museum of African American History and Culture (NMAAHC), established by Act of Congress of 2003 to promote and present the contribution of African Americans. This Museum was established in the era of the digital turn and it referred to social media as an important tool of outreach and education well before its inauguration. ${ }^{25}$ Following Sl's wellthought-out guidelines and policy, the NMAAHC's social media team established four guiding principles for its activity: to focus on the museum's mission and vision; to listen to what others are saying and sharing; to use collections to add historical context; and to be open to criticism and adjust accordingly. ${ }^{26}$ By always referring to the NMAAHC's mission and collection, by sensitizing to the views, ideas, and needs of its virtual public, and by strictly collaborating with the educational department, the NMAAHC'S social media team attempted to create a trustworthy and reliable extension of the NMAAHC in cyberspace. In its focus on issues of social justice and race, and in its activities overall, it decided not to abstain from touching upon, getting involved in, and referring to current social justice challenges and events. At the heart of such involvement and interaction is always the NMAAHC's mission - to commemorate and contextualize African American history and culture - which provides for the vital historical distance and prevents the museum from getting involved in controversial political and social issues. Thus, when Floyd's protests broke out the NMAAHC already had experience and know-how in managing the complex issue of social justice in the social media via a consistent choice of on-line lessons and references to which links could be shared. Moreover, following the principle of the One Smithsonian, it was representing the SI as a whole.

The NMAAHC is a museum established in the digital era, with social media inscribed from the beginning as a pivotal element of its policy and strategy, and an important tool for achieving its mission. Moreover, with museums devoted to various human rights issues proliferating worldwide, its focus on race and social justice and its involvement in present-day debates and events was taken for granted.

Meanwhile, the Auschwitz-Birkenau Memorial and Museum is an example of an already-established memory institution with a 60+ year tradition which turned to social media to help achieve its mission. As one of the pioneers in the use of social media in Holocaust memory institutions, the Museum inaugurated its official Facebook profile in 2009, and its @AuschwitzMuseum Twitter profile in 2012. In recent years the Museum is also present on Instagram, Pinterest, and Google Arts \& Culture. Its social media activity was launched, and has been coordinated since then, by Pawet Sawicki, a former journalist and press officer of the Museum, as yet another means of pursuing its mission. To fully grasp and understand the social media activity and policy of this memory institution, and in particular its knowhow in dealing with controversial and political issues on social media, I will present

25 L. Spruce, K. Leaf, Social Media for Social Justice, "Journal of Museum Education" 2017, Vol. 42, pp. 41-53.

26 Ibidem, p. 42. 


\section{GENERAL ARTICLES}

Ewa Manikowska

first a detailed outline of its history and of its mission, as elaborated throughout the more than 70 years now since its founding.

\section{The Auschwitz-Birkenau Memorial and Museum: The Complex Process of Universalization of a Memory Institution}

The State Auschwitz-Birkenau Museum was established in June 1947 by a bill of the Polish government. It is located on part of the territories of the former Nazi concentration camps of Auschwitz and Auschwitz II-Birkenau. ${ }^{27}$ The bill followed up on an initiative by a group of Auschwitz survivors - mainly former Polish political prisoners - and it reflected the policy and ideology of the then-Polish Communist State: to condemn fascism and Nazi Germany; to exalt the Soviet liberators of the camp; and to put into focus the resistance and martyrdom of the Polish nation. ${ }^{28}$ Thus the bill stated that the Museum was established as "a memorial to the martyrs of the Polish nation and other nations", and it made no mention of the Shoah (Holocaust). While the mission of the Auschwitz-Birkenau Museum and the meaning given to the former Nazi camp by the 1947 bill is distinctly different from its present-day interpretation, it should be stressed that it is thanks to its provisions that the Auschwitz-Birkenau complex is today the best preserved example of a Nazi concentration camp. ${ }^{29}$

An important shift in the paradigm of the Auschwitz-Birkenau Museum occurred in 1979, when following the Polish government's efforts the Museum was inscribed on the UNESCO World Heritage List. ${ }^{30}$ With this nomination, the Polish interpretation of Auschwitz - as firstly a museum-memorial of Polish martyrdom and resistance - gained a universal meaning. As Marek Kucia has justly argued, such a universalist framing of the official reading of Auschwitz through the national focus has enabled the interpretation of Polish suffering in Auschwitz to endure. ${ }^{31}$ And this despite the fact that in the Polish justification of the nomination other nationalities, including the Jewish one, were mentioned, and that moreover the site

27 Ustawa z dnia 2 lipca 1947 r. o upamiętnieniu męczeństwa narodu polskiego i innych narodów w Oświęcimiu [Law of 2 July 1947 Regarding the Commemoration of Martyrdom of the Polish Nation and Other Nations in Oświęcim], Dz.U. 1947 No. 52 item 265.

28 For more on the early history of the Auschwitz-Birkenau Museum, see Z. Wóycicka, Arrested Mourning: Memory of the Nazi Camps in Poland 1944-1950, Peter Lang, Frankfurt am Mein 2013; J. Huener, Auschwitz, Poland and the Politics of Commemoration, 1945-1979, Ohio University Press, Athens 2003.

29 J. Huener, From Liberation to Memorialization. The Transformation of the Auschwitz Site 1945-1947, "Pro Memoria" 2007, Vol. 7, pp. 9-22.

30 J. Röttjer, Safeguarding "Negative Historical Values" for the Future? Appropriating the Past in the UNESCO Cultural World Heritage Site Auschwitz-Birkenau, "Ab Imperio" 2015, Vol. 4, pp. 131-166. a Social Fact: History, Modernity and Social Awareness], Universitas, Kraków 2005. 
was presented as an essential testimony of Nazi crimes to the world. ${ }^{32}$ The central role played by the Museum as a steward of the site, of the preserved historical documents and artifacts, and as a space of research and education of international reach was exalted. ${ }^{33}$ Moreover, the importance of the Museum's activity for the peace-keeping process in the world was stressed. Thus, the implications of the 1979 inscription were far-reaching: establishing the orientation of the activities of the Museum towards preservation, research, and education, as well as international participation and dialogue. The UNESCO inscription formed the basis for an important shift in the official policy of the Polish government toward the Museum, and in addition it took place concurrently with the onset of the "Polish revolution".

In the early 1990s the Museum revised the official numbers of prisoners and victims of the camp, which had been established in 1945 by the Soviet and Polish commissions investigating the German war crimes committed in Poland. ${ }^{34}$ The estimate of 4 million victims, based on testimonies of survivors and perpetrators, was for many years the object of academic and political controversies. In Poland however, until the end of the Communist era such an estimate - which had become engrained in the wider public's consciousness reinforcing the official interpretation of the camp as a national sanctuary - was challenged only by individual researchers. Thus, the official recognition by the Museum of the estimates of Franciszek Piper - the Director of the scientific department of this institution and based on an in-depth archival and quantitative research - proving that the number of Auschwitz victims was approximately four times smaller, was shocking for the Polish society and gave rise to wider controversies. ${ }^{35}$ Moreover, Piper's quantitative research, which in the end adopted the earlier estimates of several Western scholars, ${ }^{36}$ clearly demonstrated that in terms of the national/ ethnic identities of the victims and prisoners in Auschwitz, the Jews constituted the largest group. Thus the 1990 revision marked a fundamental turn in both the national and international dimensions of the Museum. As Kucia's research based on annual public opinion polls has shown, the awareness among Polish society of the relationship between Auschwitz and the Holocaust is increasing annually. Since 1995, those interviewed have been specifically asked whether they associated Auschwitz in the first place with the martyrdom of the Polish nation, or with the Holocaust. In the first poll, only $7 \%$ of the interviewed pointed to the Holo-

32 P.R. Jenoff, Managing Memory: The Legal Status of Auschwitz-Birkenau and Resolution of Conflicts in the Post-Communist Era, "The Polish Review" 2001, Vol. 46, pp. 141-142.

33 Ibidem.

34 B. Pietka, Spory wokó liczby ofiar Auschwitz [Disputes over the Number of Auschwitz Victims], https:// bohdanpietka.wordpress.com/2016/01/25/spory-wokol-liczby-ofiar-auschwitz/ [accessed: 10.09.2020].

35 F. Piper, Auschwitz. How Many Perished Jews, Poles, Gypsies..., Frap-Books, Oświęcim 1996.

36 G. Wellers, Essai de détermination du nombre des morts au camp d'Auschwitz [An Attempt to Determine the Number of Victims of Auschwitz], "Le Monde Juif” 1983, pp. 127-159. 


\section{GENERAL ARTICLES}

Ewa Manikowska

caust; 15 years later, the same figure was $43 \% \cdot{ }^{37}$ Indeed this shift is also the result of the new educational policy developed by the Museum since 1990.

The year 1990 marked the true internationalization of the museum and site, a process which was initiated by the 1979 UNESCO inscription. As Pam R. Jenoff has rightly observed, the Museum became an essential element of the cultural and historical diplomacy of a country which, after the 1989 revolution, aimed at orienting and presenting itself as a modern democratic State. ${ }^{38}$ Moreover, with the tightening of diplomatic relations between Poland and the Western world, closer international involvement in the management of the Museum and the memory site of primordial importance for many countries and nations became possible. In the timespan of ten years, ground breaking international advisory bodies, foundations, and centres were established by the Polish government. In 1990 the Ministry of Culture and Art founded the International Council of the Auschwitz-Birkenau State Museum, with 24 world-renowned authorities on the Holocaust and German concentration camps as its members, and with Władysław Bartoszewski - the Polish diplomat, historian, and Auschwitz survivor - as its chair. This Council serves not only as an authority and advisory body of the Museum's administration, but also of the Polish Government with respect to the government's policy toward all the German concentration camp sites located in Poland. In 2005, the year of the 60th anniversary of the camp's liberation, following the Act of Foundation signed by Bartoszewski and Simone Veil on behalf of the former prisoners, the Polish Government established the International Centre for Education about Auschwitz and the Holocaust (ICEAH). The ICEAH's mission and activity is based on the Museum's tradition and experience on the one hand, and on the other was formulated in response to the evolving concept of a global Holocaust education, set up with the establishment of the International Holocaust Remembrance Alliance (IHRA) in 1998. ${ }^{39}$ Accordingly, on the occasion of the 60th anniversary of the camp's liberation, the European Parliament issued the Resolution on Remembrance of the Holocaust, Anti-Semitism and Racism, which explicitly stated that the Museum is among the main European resources of Holocaust education, ${ }^{40}$ and the UN's General Assembly passed the Resolution on Holocaust Remembrance, which among other things established 27 January, the day of Auschwitz's liberation, as the International Day

37 S. Klauziński, W polskiej pamięci o wojnie Auschwitz kilka razy ważniejsze niż Powstanie Warszawskie i Katyń [In the Polish Memory of the War Auschwitz Is Several Times More Important than the Warsaw Uprising and Katyn], "OkoPress", 17 January 2020, https://oko.press/w-polskiej-pamieci-o-wojnie-auschwitz-kilkarazy-wazniejsze-niz-powstanie-warszawskie-i-katyn/ [accessed: 10.09.2020].

38 P.R. Jenoff, op. cit.

39 A. Mihr, Why Holocaust Education is not Always Human Rights Education?, "Journal of Human Rights" 2015, Vol. 14, pp. 525-544; M. Kucia, The Europeanization of Holocaust Memory in Eastern Europe, "East European Politics and Societies" 2016, Vol. 30, pp. 97-119. 
of Commemoration in Memory of the Victims of Holocaust, and set the grounds for the Holocaust and the United Nations Outreach Programme. ${ }^{41}$ Then in 2009, based on the initiative of Bartoszewski and with the diplomatic support of the Polish Government, the Auschwitz-Birkenau Foundation ${ }^{42}$ was established with the aim of creating a Perpetual Capital of $€ 120,000$ to finance the Global Preservation Plan (or Master Plan for Preservation), a long-term programme aimed at expert conservation and preservation of the remains of the camp (which contains such difficult and vulnerable items as deteriorated wooden and brick barracks, wooden guard towers, and old and worn suitcases). ${ }^{43}$

By establishing a network of foundations, centres, and advisory bodies, the Polish Government has created a governance model of the Museum involving the international community, Auschwitz survivors, and Holocaust scholars from around the world, as well as the local society and authorities. Moreover, it has given a large space of autonomy to this memory institution. Indeed, in a short time-span the Museum has successfully adopted innovative solutions, which inter alia enable it to consider and weigh the different, often competing or even mutually-exclusive opinions and needs, including those of a diplomatic, political, or ideological nature, of the various parties interested or directly involved in the decision-making process related to all aspects of this heritage site. In particular, the Museum is over and over again confronted with fundamental questions about the forms of Holocaust remembrance, education, the role of the Museum and site in this process, the camp's victims, and the ever-recurring question: To whom does the moral legacy of this heritage site truly belong?

Such a governance model and the tasks of the Museum have evolved in the last decade in view of new political, social, and cultural phenomena. Its new mission statement, drafted in anticipation of the 70th anniversary of the liberation of the camp, reflected the numerous political, social, cultural, and academic changes, developments, and trends which in the previous 20 years had affected the activity of the Museum, as well as the developments shaping this institution since its founding. These included, inter alia, the Polish revolution; the EU enlargement (i.e. to include Poland); globalization; the rise of memory studies; the rise of Holocaust memory institutions worldwide; and the internationalization of Holocaust remembrance and education. In this document Auschwitz is defined as the "most recognizable symbol and place of genocide in the world. [...] A constant point of reference in the post-war history of the Old Continent, fully justifying all the efforts aimed at creat-

41 United Nations General Assembly, Resolution 60/7: Holocaust Remembrance, 1 November 2005, A/RES/60/7, https://undocs.org/A/RES/60/7 [accessed: 24.10.2020].

42 http://www.foundation.auschwitz.org/ [accessed: 20.09.2020].

43 Auschwitz-Birkenau Memorial and Museum, Master Plan for Preservation, http://ftp.auschwitz.org/en/ museum/preservation/master-plan-for-preservation [accessed: 10.09.2020]. 


\section{GENERAL ARTICLES}

Ewa Manikowska

ing a unified, different, new, more humane and sensitive Europe". ${ }^{44}$ The protection of the site is defined as "an obligation towards the past generations, victims and survivors" as well as "an obligation towards the generations to come. It will be their responsibility to carry on our post-war endeavours for a better, united, sensible, supporting and safe world". ${ }^{45}$ According to the mission statement the Museum is thus in the first instance imbued with a European and universal meaning and represents primordial humanistic values.

\section{Online Community of Remembrance:}

\section{The Auschwitz-Birkenau Memorial and Museum's Social Media}

The Museum's various types of social media were established at the time of the reformulation of its mission statement, and they reflect the new ideas standing behind them. Moreover, they are performed in symbiosis with educational programmes and on-line initiatives of the ICEAH and in the larger framework of the proliferation of IT in the institution's activities. Given the complex copyright status of Holocaust documents, photographs, objects, and other types of memorabilia, ${ }^{46}$ digitization, while in use, does yet not constitute an important focus of the Museum. The new IT opportunities are exploited in the first instance in education. The ICEAH's e-learning section was established in 2012, inaugurating its activities with its first on-line lesson, entitled Auschwitz - Concentration and Extermination Camp. Since that time the number of e-lessons has expanded to 19.47 Prepared by or in collaboration with Holocaust scholars, they offer an in-depth focus on different aspects of Auschwitz and its history, including among others an insight into how to prepare for a visit to this memory site. Recently, such lessons are also posted in form of virtual exhibitions in the framework of Google Arts \& Culture. ${ }^{48}$ The Auschwitz virtual panorama, made available in November 2011 following a two-year digitization project, is composed of around 200 high quality 360 degree panoramic digital photographs of the site, including buildings which are not on view during regular visits to the camp, links to on-line lessons, witness testimonies, digitized documents, photographs, and objects which shed light on the history of the camp. ${ }^{49}$ Thus the panorama, the on-line lessons, and the Google

\footnotetext{
44 Auschwitz-Birkenau Memorial and Museum, Mission Statement, http://70.auschwitz.org/index.php?option=com_content\&view=article\&id=76\&ltemid=173\&lang=en [accessed: 10.09.2020].

45 Ibidem.

46 G. Pessach, M. Shur-Ofry, Copyright and the Holocaust, "Yale Journal of Law and the Humanities" 2018, Vol. 30.

47 Auschwitz-Birkenau Memorial and Museum, E-learning, http://auschwitz.org/en/education/e-learning/ [accessed: 10.09.2020].

48 https://artsandculture.google.com/partner/auschwitz-birkenau-state-museum [accessed: 10.09.2020].

49 http://panorama.auschwitz.org/ [accessed: 10.09.2020].
} 
virtual exhibitions are addressed to Auschwitz visitors who want to deepen their knowledge, to those who want to prepare for a visit, as well as to those who can visit it only in the virtual space.

Social media reinforces the Museum's educational programmes and commemoration events. Social media tasks are performed through consistent and wellthought-out initiatives, which aim on the one hand at informing the on-line community about the everyday history of the camp, and on the other at involving it about the current celebrations, events, and anniversaries. A good example of the first task is the recent and very successful Twitter project, within the framework of which every two hours a short informational note is posted about an Auschwitz prisoner who was born or died on the given day. By means of a timeline social media modality, the Museum every two hours, and every time with a different post, is reminding recipients about Auschwitz and its heritage. The posts are addressed both to those who have never been to Auschwitz as well as to former visitors. ${ }^{50}$ Indeed, in a 90-minute tour it is impossible to give insights and to commemorate the individual prisoners and victims of the camp. Moreover, the project is in line with the general idea of Holocaust education, which among other things calls for humanizing the statistics of the horrors and atrocities: "Sadly, we do not know all the names \& most names cannot be linked with a face. We are gathering the pieces $\&$ humanizing tragic statistics". ${ }^{51}$ In this long-term and evolving project, the Museum regularly reminds its Twitter community about the vast scale of the Holocaust at Auschwitz, as follows:

12 people a day. One person every two hours. We know that names \& faces appearing so often on your @Twitter feeds may be uncomfortable. On the other hand, 12 people a day is 4380 people a year -0.33 per cent of those deported to \#Auschwitz. A drop in the ocean of human tragedy. ${ }^{52}$

A good example of the second type of social media projects are the programmes conceived on the occasion of specific events, like the 2014 commemorations and educational activities dedicated to the deportations to Auschwitz of Jews from Hungary. ${ }^{53}$ Between the end of April and mid-July 2014 the Museum posted, in particular on its Facebook profile, short reminders of basic facts, short fragments of witness testimonies, historical photographs and documents. These posts were aimed at linking basic historical facts and data with the human and emotional contexts of

50 Holocaust Remembrance Alliance, Using Social Media in Holocaust Education, https://www.holocaustremembrance.com/educational-materials/using-social-media-holocaust-education [accessed: 20.09.2020].

51 https://twitter.com/AuschwitzMuseum/status/1282710059210940422 [accessed: 10.09.2020].

52 https://twitter.com/AuschwitzMuseum/status/1278955328588169218 [accessed: 10.09.2020].

53 Auschwitz-Birkenau Memorial and Museum, 70th Anniversary of the Extermination of Jews from Hungary. Living Community of Memory On-line, 24 April 2014, http://auschwitz.org/en/museum/news/70th-anniversary-of-extermination-of-jews-from-hungary-living-community-of-memory-on-line-,1072.html [accessed: 10.09.2020]. 


\section{GENERAL ARTICLES}

Ewa Manikowska

these dramatic events. The programme was conceived in strict collaboration with the ICEAH, which prepared a special on-line lesson in English and Polish language versions entitled Deportations of Hungarian Jews to Auschwitz, giving not only an indepth explanation of the deportations/exterminations but also a large overview of the history of the pre-war community of Jews in Hungary. It also included links to former prisoners' testimonies, multimedia, photographs, maps, and archival documents. ${ }^{54}$ The campaign was conducted under the heading "[A] Living community of memory on-line", which links it with one of the main aims of the Museum's social media activities - to keep the knowledge and memory about Auschwitz alive and to expand it among society by means of the internet. Every now and then the @AuschwitzMuseum Twitter profile posts a message which clearly explains this aim:

Our mission is to commemorate all victims, preserve the authentic site \& educate about the tragic history of \#Auschwitz. Thanks to all of you, our voice can be heard here. Help us. Share our tweets \& encourage others to follow @AuschwitzMuseum. \#WeRemember together. ${ }^{55}$

The constant enlargement of the online community of remembrance is crucial for the Museum's social media strategy. Its size is not considered as an indicator of success or of the institution's recognition, but rather as an important means of outreach and education. Among the main tasks of the Museum's social media activity is the rectifying of simplifications and misinformation about Auschwitz which are posted on the internet, appear in popular culture broadcasting, are used in politics, or published as "academic" findings. As media outlets, politicians, celebrities, and even scholars ever more often refer to and engage with the social network in spreading news, opinions, and findings, the cyberspace is ever more substituting the traditional spaces of debate and education. Thus the team regularly conducts fact-checking of media outlets and user content by using the search terms "Holocaust" and "Auschwitz" and promptly correcting wrong and false information via the Museum's social media, in particular Twitter. ${ }^{56}$ Importantly, such activity is orientated toward education and commemoration, which are the cornerstones of the Museum's mission in the first place. A good example of this social media strategy is the Museum's recent reaction to the TikTok trend of acting as Holocaust victims. While the short and disturbing videos marked with the hashtags \#Holocaust or \#Haven - usually played out by very young people - have been condemned by many social media users, the Museum decided to join in the discussion in a different way; by explaining the inappropriateness of such videos ("The victims trend on TikTok

54 http://pl.auschwitz.org/lekcja/6_dep_zydow_eng/story_html5.html [accessed: 10.09.2020].

$55 \mathrm{https} / / /$ twitter.com/AuschwitzMuseum/status/1180822958803161089 [accessed: 10.09.2020].

56 D. Spilberger, How the Auschwitz Memorial's Twitter Account Became the Internet's Holocaust's Fact Checker, "The Insider", 27 January 2020, https://www.insider.com/auschwitz-memorial-museum-twitter-internet-holocaust-fact-checker-paul-sawicki-2020-1 [accessed: 20.09.2020]. 
can be hurtful and offensive. Some videos are dangerously close or already beyond the border of trivialization of history") while at the same time being sensitive to the complex motivations behind them ("... but we should discuss this not to shame and attack young people, whose motivations seem very diverse. It's an educational challenge"). ${ }^{57}$ The expanding Twitter community of the @AuschwitzMuseum, which in the last year exceeded one million, provided the resonance of the thoughtful message and acted as a reinforcement of the Museum's authority in social media. Another interesting example of the growing role of social media in the Museum's strategy and mission is the recent collaboration project between Marina Amaral and the ICEAH. Amaral, a self-taught digital colourization specialist, used the occasion of the 2017 Holocaust Remembrance Day to colourize one of the pictures of the Auschwitz photographer Wilhelm Brasse. ${ }^{58}$ She uploaded the digitized picture representing Czesława Kwoka, a Polish 14-year old Auschwitz victim, from Wikipedia without consulting the Museum, where Brasse's photo archive is kept.59 The very evocative and lifelike image shared on her blog has met with an unprecedented popularity: it was shared and liked by thousands of Twitter users, and shown and discussed in main newspapers and broadcast programmes worldwide. ${ }^{60}$ The Museum, via its social media, promptly responded to the uncontrolled popularity that the photograph was gaining in cyberspace. In fact, in the subsequent shares and likes of the picture in the social network Kwoka was transformed from a Pole into a Jew, and the documentary, archival, and historical context of the photograph was gradually lost. The Museum, while appreciating Amaral's work as an example of another iconic photographic image of the Holocaust and of the engagement of contemporary artists with Holocaust photography, foresaw a wider ongoing cultural phenomenon in its social media popularity; one which might bring a serious and problematic shift in the way we perceive the Holocaust and understand historical visual evidence. Amaral's picture was thus shared several times on the @AuschwitzMuseum Twitter account with links to Auschwitz and to the historical context of the photograph. Moreover, in March 2018 the Museum decided to engage in Amaral's larger project, entitled Faces of Auschwitz, which was made possible thanks to the generosity of the Michael Frank Family Charitable Fund. ${ }^{61}$ Aimed at colourizing all of Brasse's archive of black and white photographs of Auschwitz prisoners and victims and at making them available on-line along with their recon-

\footnotetext{
57 J. Fink, Auschwitz Museum Calls for Education after "Hurtful" TikTok Holocaust "Victim" Videos Posted, "Newsweek", 27 August 2020, https://www.newsweek.com/auschwitz-museum-calls-education-after-hurtful-tiktok-holocaust-victim-videos-posted-1528116 [accessed: 10.09.2020].

58 https://marinamaral.com/in-memory-of-czeslawa-kwoka/ [accessed: 20.09.2020].

59 Uploaded on Wikipedia by an anonymous user in 2008: https://en.wikipedia.org/wiki/Czes\%C5\%82awa_Kwoka [accessed: 20.09.2020].

60 On the project's reception see https://facesofauschwitz.com/media/ [accessed: 20.09.2020].

61 https://twitter.com/facesauschwitz?lang=pl [accessed: 20.06.2019].
} 


\section{GENERAL ARTICLES}

Ewa Manikowska

structed stories, this constitutes an innovative educational and commemorative project which makes use of the possibilities given by digitization, the Internet, and social media. The Museum provides access to the archival photographs as well to archival documents and other material and assists Amaral's team in writing and ensuring an accurate historical and educational content to the project. It also incorporates the project in its own social media, posting the coloured photographs, together with accurate information on the victim and important historical details, on its Facebook and Twitter accounts. The project itself is not only shared via the Museum's and Amaral's social media and blog, but it also has a special Twitter account linked to the Museum, as well as a website based on the best examples of Holocaust Educational sites, providing access not only to the outcomes of the project, but also to basic information about the Holocaust, Auschwitz, and the archival collection of photographs in the holdings of the Museum. This collaborative project illustrates the fundamental role that memory institutions can play in taming the uncontrolled flow of trivialized and falsified information, often graphic in nature, relating to the Holocaust in social media such as Facebook, Twitter, Flickart, or Pinterest. In the case of content relating to the Holocaust they usually exploit archival, library, or museum materials accessible in the public domain, such as historic photographs or images of museum exhibits. Thus, a memory institution can play an important role in re-contextualizing such images and using such bottom-up initiatives in the process of Holocaust education.

\section{Social Media Guidelines and Codes of Conduct in Holocaust Education and Commemoration}

Unlike the NMAACH, the Auschwitz-Birkenau Museum's social media activity refers not to a specific and detailed set of social media guidelines and policies, but is based on the general principles of Holocaust education and commemoration. In particular, the IHRA has elaborated a set of general and specific Recommendations for Teaching and Learning about the Holocaust, which since 2011 also include guidelines referring to social media. ${ }^{62}$ Offering a general explanation concerning social media, its potential in education and how to use it, the guidelines provide specific recommendations referring to Holocaust education. Indeed, the appropriateness in the use of images and of the vocabulary, as well as stress on historical context and accuracy of the posts, form the pillars of Holocaust education in general and in social media in particular. Given the visual character of the medium, which can refer to historical photographs or videos, together with testimonies of survivors, the development of historical empathy and the "humanization" of the Holocaust are stressed and recognized as the core aims of Hol-

62 Holocaust Remembrance Alliance, op. cit. 
ocaust education performed via social media. Indeed, Holocaust education and commemoration requires ethical awareness and concerns, and the application of social media in Holocaust museums and memorials was from the beginning more risk-aware and in full compliance with their mission than in most other types of memory institutions. ${ }^{63}$

Holocaust education is constantly evolving and must take into account the new threats and challenges posed by the prevailing ignorance about the Holocaust in Generations $Y$ and $Z$; the inevitable end of the eye-witness era; the recent rise of anti-Semitism and right-wing movements; and the growing role of the internet and social media as a means of information and space for all types of discussions, including those based on misinformation or with misguided intentions. Recently, UNESCO has strongly interlinked it with Global Citizenship Education, a pillar of the UNESCO Education 2030 Agenda, and commissioned a detailed policy guide on Education about the Holocaust and Preventing Genocide, based on years of research and experiences in Holocaust education, and prepared in consultation with Holocaust- and genocide-related organizations, academics, and educators worldwide. ${ }^{64}$ Moreover, in collaboration with the Organization for Security and Co-Operation in Europe it has developed guidelines for policymakers on how to address anti-Semitism through education - an issue central for Holocaust education. ${ }^{65}$ Museums and memorials are considered key institutions of implementing Holocaust and global citizenship education and are indeed at the forefront of the new challenges and threats. In particular, the Auschwitz-Birkenau Memorial and Museum is nowadays one of the leading institutions in the battle against Holocaust denial, misinformation, glorification, and other forms of human rights violations referring to Auschwitz which are eagerly spread via social media. Recently, through its social media accounts the Museum has joined and propagated the survivors' call on Mark Zuckerberg to remove Holocaust denial from Facebook. ${ }^{66}$ Accordingly, the Museum's voice is important in the general discussion on the ethics of social media and in the quest for cyber justice. ${ }^{67}$

63 A.S. Wong, Ethical Issues of Social Media in Museums: A Case Study, "Museum Management and Curatorship" 2011, Vol. 26, pp. 97-112.

64 United Nations General Assembly, Resolution 70/1: Transforming our World: the 2030 Agenda for Sustainable Development, 25 September 2015, A/RES/70/1, https://undocs.org/A/RES/70/1 [accessed: 20.09.2020].

65 UNESCO, OSCE, Addressing Anti-Semitism through Education. Guidelines for Policymakers, Paris-Warsaw 2018, https://unesdoc.unesco.org/ark:/48223/pf0000263702 [accessed: 20.09.2020].

66 E. Palmer, Holocaust Survivors are Repeatedly Asking Mark Zuckerberg to Ban Denial on Facebook, "Newsweek", 29 July 2020, https://www.newsweek.com/holocaust-denial-banned-facebook-survivors-1521039 [accessed: 20.09.2020].

67 On cyber justice and on the efforts of introducing a social contract regarding the cyberspace see A. Mihr, Cyber Justice. Human Rights and Good Governance for the Internet, Springer, Berlin 2017. 


\section{GENERAL ARTICLES}

Ewa Manikowska

The Museum's strong embedding in general ethical and educational principles and guidelines and its more than 60-years' experience in dealing with and taming the controversies surrounding Auschwitz lie at the heart of its social media activities. For over two years now the Museum has been confronting unprecedented attacks on its autonomy, its mission, and on the values expressed in its mission statement from part of the Polish right-wing activists, politicians, and even official authorities. Such attacks are played out and popularized mainly via social media.

\section{The Auschwitz-Birkenau Memorial and Museum and the Traps of Social Media}

The 75th anniversary of the liberation of Auschwitz - which also marked the 20th anniversary of the adoption of the Stockholm Declaration, ${ }^{68}$ the founding document of the IHRA, and the 15th anniversary of the adoption of 27 January as the International Holocaust Remembrance Day by the UN General Assembly - was deeply affected by another outbreak in a creeping political conflict. Two years earlier Poland adopted the so-called "Holocaust Law", an amendment to the Act of the Institute of National Remembrance. ${ }^{69}$ According to its provisions, the Institute, a public entity established in 1998 to deal with the legacy of its Communist past via investigation into and prosecution of, inter alia, war-time and Communist-era crimes, was in addition obliged to prosecute any individual who or institution which claimed that the Polish nation or the Polish State were co-responsible for the Holocaust. ${ }^{70}$ This ideologically-driven amendment compelled the Polish authorities to sue anyone, whether in Poland or abroad, who used the expressions "Polish death camps" or "Polish concentration camps" - expressions which were used unintentionally and sporadically by journalists, politicians, the media, and ordinary people with reference to the current geopolitical location of Auschwitz and other former Nazi concentration camps. Moreover, it formed a serious threat to ongoing academic research into the Holocaust, in which the dark sides of Polish-Jewish relations form an important area of study. ${ }^{71}$ Thus, the "Holocaust Law" was justly criticized both in Poland and abroad as a threat to freedom of speech and to the freedom of historical debate. Moreover, the amendment, dictated

68 Declaration of the Stockholm International Forum on the Holocaust, 26-28 January 2000, https://tandis.odihr.pl/bitstream/20.500.12389/19314/1/00576.pdf [accessed: 10.09.2020].

69 For a concise discussion of the "Holocaust Law" see M. Bucholc, M. Komornik, The Polish 'Holocaust Law' Revisited: The Devastating Effects of Prejudice-Mongering, "Cultures of History Forum", 19 February 2019, https://www.cultures-of-history.uni-jena.de/politics/poland/the-polish-holocaust-law-revisited-the-devastating-effects-of-prejudice-mongering/ [accessed: 10.09.2020].

70 D. Stola, Poland's Institute of National Remembrance: A Ministry of Memory?, in: M. Lipman, A. Miller (eds.), The Convulsions of Historical Politics, CEU Press, Budapest 2012, pp. 45-58.

71 J.B. Michlic, 'At the Crossroads': Jedwabne and Polish Historiography of the Holocaust, "Dapim: Studies on the Holocaust" 2017, Vol. 31, pp. 296-306. 
solely based on internal political needs, sparked a diplomatic conflict with Israel, forcing the Polish authorities to rapidly amend some of its provisions. Still, the social, cultural, and political implications of the "Holocaust Law" were devastating and far-reaching, affecting Poland's international reputation, the public debate in the country, and the activities of Polish memory institutions dealing with the legacy of the Holocaust.

The autonomy and authority of such internationally established museums, memorials, and research centres as the Auschwitz-Birkenau Memorial and Museum and the Museum of Polish Jews were put at stake when, following the controversies surrounding the "Holocaust Law", they became unwillingly involved in a brutal political debate. On the occasion of the 73rd anniversary of the liberation of Auschwitz, celebrated a few days after the amendment of the "Holocaust Law" by the Polish Parliament, the Auschwitz-Birkenau Memorial and Museum was a victim of a media attack without precedent from the side of right-wing politicians, publicists, and anonymous users of the internet. By spreading false news about the Museum's activities, the authors aimed to discredit this institution and make it co-responsible for the failure and international embarrassment of Polish Holocaust diplomacy. Polish social media was literally flooded by fake news and disinformation about the Museum and the 73rd anniversary, such as: the alleged removal of a Polish flag during the celebrations; the alleged ban on singing the Polish anthem in the camp area; the alleged devastation of the preserved traces of Polish Auschwitz prisoners; the alleged lack of a Polish exhibition; the alleged absence of Polish survivors at the anniversary, etc. ${ }^{72}$ Two years later, the 75 th anniversary was clouded by a public breakdown in Russian-Polish diplomatic relations following Vladimir Putin's official statement that Poland was partly responsible for the Second World War. ${ }^{73}$ Such historical revisionism, used as an official diplomatic tool, not only politicized the anniversary but led to its breaking down into two competing events - one in the Yad Vashem, which featured Vladimir Putin among the official speakers, was boycotted by the Polish president Andrzej Duda; and in turn Putin was not invited by the Polish authorities to the anniversary organized by the Auschwitz-Birkenau Memorial and Museum.

Despite such devastating circumstances, both in 2018 and in 2020 the Museum managed to effectively depoliticize the anniversary celebrations by manifesting the universal values standing behind the International Holocaust Remembrance Day. An important role in this process was played by the Museum's official internet information policy, pursued in particular through its social media accounts.

\footnotetext{
72 G. Kendall Adams, Auschwitz-Birkenau Museum Suffers Wave of Abuse Following New Law, "Museums Association News", 14 May 2018, https://www.museumsassociation.org/museums-journal/news/14052018auschwitz-birkenau-wave-of-abuse [accessed: 10.09.2020].

73 Ch. Carly, Russia and Poland are Playing Political Games with the Holocaust, "The Washington Post", 23 January 2020, https://www.washingtonpost.com/opinions/2020/01/23/russia-poland-are-playing-political-games-with-holocaust/ [accessed: 10.08.2020].
} 


\section{GENERAL ARTICLES}

Ewa Manikowska

In 2018, by means of Twitter, the Museum managed to immediately correct every piece of disinformation, fake news, and accusations. Moreover, in June 2019 it published on its official webpage an announcement in Polish (the disinformation was disseminated in Polish by Polish internet users) entitled Fake newsy pojawiaja sie także w obszarze Pamięci (Fake News Also Appears in the Sphere of Memory) listing and explaining the main items of disinformation about the institution and the heritage of Auschwitz which had appeared on the internet following the adoption of the "Holocaust Law". ${ }^{74}$ In 2020, thanks to its on-line coverage of the celebrations and in particular to its recurring posts on its Twitter account - the Museum built up in the general public an immediate association of the anniversary with a powerful quotation from one of the speeches, which overshadowed the political disputes and controversies surrounding the celebrations. The words of 94-year-old Marian Turski, a Holocaust survivor, resounded in the Museum on 27 January 2020: "If you are indifferent, you will not even notice it when upon your own heads, and upon the heads of your descendants, some other Auschwitz falls from the sky". These words were headlined in the main Polish and international newspapers and repeated in the following weeks and months in the official Museum social media accounts, becoming a memorable quote to be preserved and invoked, like Primo Levi's "It happened, therefore it can happen again... it can happen anywhere!"; or Charlotte Delbo's "They expected the worst - not the unthinkable". ${ }^{75}$

The Museum, with its know-how, experience, autonomy, and embedment in the universal principles of Holocaust commemoration and education, is successfully using the mass and un-hierarchical nature of social media to correct fake news, disinformation, and even digital aggression concerning Auschwitz and the Holocaust posted and shared on social media. In particular, using this means the Museum is able to respond to political and instrumental misuses and abuses, and to the attempts to involve this institution in a political and ideological conflict. In its prompt, real-time, social media responses to contemporary events and controversies, the Museum is always guided by its mission and the general ethical principles of Holocaust commemoration and education. Thus, its social media activity in face of the controversies surrounding the 73rd and 75th anniversaries of the liberation of Auschwitz was inscribed in the larger framework of the response of Holocaust memory institutions to the dramatic increase of anti-Semitism in social media. ${ }^{76}$

74 Państwowe Muzeum Auschwitz-Birkenau, Fake newsy pojawiaja się także w obszarze Pamięci, 10 June 2019, http://auschwitz.org/muzeum/aktualnosci/fake-newsy-pojawiaja-sie-takze-w-obszarze-pamieci,1965.html [accessed: 10.09.2020].

75 Anniversary Quotes. Available on-line on the Museum's website: http://70.auschwitz.org/index. php?option=com_content\&view=article\&id=45\&ltemid=159\&lang=en [accessed: 10.09.2020].

76 World Jewish Congress, Anti-Semitic Symbols and Holocaust Denial in Social Media Posts, January 2018, https://www.worldjewishcongress.org/download/3KVjYgi8FNOTxdWd5HeFPw?utm_source=PRESS\&utm_campaign=3d806f4ab8-EMAIL_CAMPAIGN_2018_02_08\&utm_medium=email\& utm_term $=0 \_c 3 b 21 e 69 b 1-3 \mathrm{~d} 806 f 4 a b 8-\& u t m_{-}$source $=W J C+$ Mailing+Lists\&utm_campaign $=78 b-$ 


\section{Conclusions}

In 2017, several American museum professionals, educators, and activists founded - under the slogan "Museums are Not Neutral" - a successful and ongoing online movement calling upon museums and heritage organizations to engage in relevant social and political issues, and in particular to fight against racism, sexism, or injustice of any kind within memory institutions. ${ }^{77}$ Also in recent years groups of environmental activists organized social protests and performances in the spaces of important museums - among others the Tate, the Louvre, the Van Gogh Museum - protesting against sponsorship deals made by memory institutions with oil companies. ${ }^{78}$ In summer 2020 the Congolese activist, Mwazulu Diyabanza, organized performances at the Quai Branly Museum and in the Afrika Museum in Berg en Dal during which - after accusing the museums of colonial era theft - he attempted to remove artefacts from the exhibitions. ${ }^{79}$ These protests and movements are just a few examples of the recent and growing phenomenon of museum activism, which focuses in particular on the issues of social justice, the environment, and colonialism. These recent performances and movements rely on social media: the "Museums are Not Neutral" was based on a Twitter campaign; the activists from "BP or Not BP" used social media to inform and popularize their performances and actions against the involvement of British museums and cultural institutions with BP; and Diyabanza's manifesto and performance was live-streamed on Facebook.

The involvement of museums in social media and the rise of museum activism has accelerated the transformations going on in museums since the emergence of New Museology in the 1980s, with its postulates of including the larger society in museum work and practice. ${ }^{80}$ Museum activism is nowadays no longer just a bottom-up phenomenon, but is initiated by the memory institutions themselves. The last dozen years have seen a proliferation of museums, such as the NMAAHC, which put issues of social justice, human rights, or environment at the heart of their mission. Moreover, many established memory institutions have integrated important contemporary social issues into their programmes and missions. The Auschwitz-Birkenau Memorial and Museum's campaigns against Holocaust denial and anti-Semitism are a good example of this.

fed156d-EMAIL_CAMPAIGN_2018_02_08\&utm_medium=email\&utm_term=0_04292c525e-78bfed15 6d-318920277 [accessed: 20.09.2020].

77 https://www.museumsarenotneutral.com/learn-more/monument-lab [accessed: 10.10.2020].

78 K. Massara, Environmental Activists Focus on Museums that Take Oil Money, "The New York Times", 9 October 2018, https://www.nytimes.com/2018/10/09/business/environmental-activists-take-on-oil-money. html [accessed: 20.09.2020].

79 A. Marshall, To Protest Colonialism, He Takes Artifacts from Museums, "The New York Times", 21 September 2020, https://www.nytimes.com/2020/09/21/arts/design/france-museum-quai-branly.html [accessed: 10.10 .2020$]$.

80 M. Ross, Interpreting the New Museology, "Museums and Society” 2004, Vol. 2, pp. 84-103. 


\section{GENERAL ARTICLES}

Ewa Manikowska

The growing importance of museum and heritage activism is well reflected in the recent proposal of the International Council of Museums (ICOM) to change the definition of "museum" which has been functioning since 1947. While the idea of redefining museum institutions as "democratizing, inclusive and polyphonic spaces for critical dialogue about the pasts and futures" 81 was met with a wave of criticism from the side of museums with a long tradition, and the debate was postponed to an indefinite time, museums worldwide are indeed under social pressure to respond to contemporary social, political, and ideological debates - either spontaneously or engaging in such debates and controversies as part of their mission.

As has been shown in this article, social media have nowadays become the main space where sound social, cultural, and political debates are played out. Indeed, even such well-established institutions as the Met, the Getty Museum, or the British Museum should - given their social media involvement - be considered nowadays "spaces for critical dialogue". The examples of the SI and of the Auschwitz-Birkenau Memorial and Museum, which have elaborated their social media strategies, good practices, and guidelines in connection with a larger redefinition of their mission, policies, and strategies and even broader concepts of museum ethics and education, shows that this new realm of museum activity can be channelled and integrated with the traditional museum functions. Moreover, as the example of the Auschwitz-Birkenau Memorial and Museum shows, well-thoughtout social media policies which are firmly integrated with the museum's mission reinforce the institution's authority, give credibility to its posts and positions, and reinforce the values for which it stands.

\section{References}

Anderson M. et al., Activism in the Social Media Age, 11 July 2018, https://www.pewresearch. org/internet/2018/07/11/activism-in-the-social-media-age/ [accessed: 10.09.2020].

Auschwitz-Birkenau Memorial and Museum, 70th Anniversary of the Extermination of Jews from Hungary. Living Community of Memory On-line, 24 April 2014, http://auschwitz.org/ en/museum/news/70th-anniversary-of-extermination-of-jews-from-hungary-living-community-of-memory-on-line-,1072.html [accessed: 10.09.2020].

Auschwitz-Birkenau Memorial and Museum, E-learning, http://auschwitz.org/en/education/e-learning/ [accessed: 10.09.2020].

Auschwitz-Birkenau Memorial and Museum, Master Plan for Preservation, http://ftp. auschwitz.org/en/museum/preservation/master-plan-for-preservation [accessed: 10.09.2020].

Auschwitz-Birkenau Memorial and Museum, Mission Statement, http://70.auschwitz.org/index.php?option=com_content\&view=article\&id=76\&ltemid=173\&lang=en [accessed: 10.09.2020].

Baggesen R.H., Augmenting the Agora: Media and Civic Engagement in Museums, "MediaKultur: Journal of Media and Communication Research" 2014, Vol. 30. 
British Museum, Social Media Code of Conduct, https://www.britishmuseum.org/terms-use/ social-media-code-conduct [accessed: 10.09.2020].

Brown K., 'This Is Performative': Critics Mercilessly Mock the British Museum for Its 'Hollow' Statement of Solidarity with the Black Live Matter Movement, "Artnet News", 9 June 2020, https://news.artnet.com/art-world/british-museum-black-lives-matter-1882296 [accessed: 20.09.2020].

Bucholc M., Komornik M., The Polish 'Holocaust Law' Revisited: The Devastating Effects of Prejudice-Mongering, "Cultures of History Forum", 19 February 2019, https://www. cultures-of-history.uni-jena.de/politics/poland/the-polish-holocaust-law-revisited-the-devastating-effects-of-prejudice-mongering/ [accessed: 10.09.2020].

Carly Ch., Russia and Poland are Playing Political Games with the Holocaust, "The Washington Post", 23 January 2020, https://www.washingtonpost.com/opinions/2020/01/23/ russia-poland-are-playing-political-games-with-holocaust/ [accessed: 10.08.2020].

Charr M., How Have Museums Responded to the Black Live Matters Protests?, "MuseumNext", 20 June 2020, https://www.museumnext.com/article/how-have-museums-responded-to-the-black-lives-matter-protests/ [accessed: 10.09.2020].

Declaration of the Stockholm International Forum on the Holocaust, 26-28 January 2000, https://tandis.odihr.pl/bitstream/20.500.12389/19314/1/00576.pdf [accessed: 10.09.2020].

Edson M., Fast, Open and Transparent. Developing the Smithsonian's Web and New Media Strategy, in: J. Trant, D. Bearman (eds.), Museums and the Web 2010: Proceedings, Archives \& Museum Informatics, Toronto 2010, https://www.museumsandtheweb.com/ mw2010/papers/edson/edson.html [accessed: 10.09.2020].

Fink J., Auschwitz Museum Calls for Education after "Hurtful" TikTok Holocaust "Victim" Videos Posted, "Newsweek", 27 August 2020, https://www.newsweek.com/auschwitz-museum-calls-education-after-hurtful-tiktok-holocaust-victim-videos-posted-1528116 [accessed: 10.09.2020].

Flynn N., The Social Media Handbook. Rules, Policies and Best Practices to Successfully Manage Your Organization's Social Media Presence, Posts and Potential, John Wiley \& Sons, Hoboken 2012.

Greenberger A., Solomon T., Major U.S. Museums Criticized for Responses to Ongoing George Floyd Protests, "ArtNews", 2 June 2020, https://www.artnews.com/art-news/news/ museums-controversy-george-floyd-protests-1202689494/ [accessed: 10.09.2020].

Harris G., 'Racist' Gallery in Liverpool Museum to be Overhauled in Light of Black Life Matters, "The Art Newspaper", 13 July 2020, https://www.theartnewspaper.com/news/racist-liverpool-museum-gallery-to-be-reconfigured-in-light-of-black-lives-matter [accessed: 20.09.2020].

Hicks D., The Brutish Museum. The Benin Bronzes, Colonial Violence and Cultural Restitution, Pluto Press, London 2020 [forthcoming].

Holocaust Remembrance Alliance, Using Social Media in Holocaust Education, https:// www.holocaustremembrance.com/educational-materials/using-social-media-holocaust-education [accessed: 20.09.2020].

Huener J., Auschwitz, Poland and the Politics of Commemoration, 1945-1979, Ohio University Press, Athens 2003.

Huener J., From Liberation to Memorialization. The Transformation of the Auschwitz Site 1945-1947, "Pro Memoria” 2007, Vol. 7. 


\section{GENERAL ARTICLES}

Ewa Manikowska

J. Paul Getty Trust, J. Paul Getty Trust Social Media Policy, September 2019, https://www. getty.edu/staff/forms/socialmedia.pdf [accessed: 10.09.2020].

Janes R.R., Sandell R. (eds.), Museum Activism, Routledge, London 2019.

Jenoff P.R., Managing Memory: The Legal Status of Auschwitz-Birkenau and Resolution of Conflicts in the Post-Communist Era, "The Polish Review" 2001, Vol. 46.

Kendall Adams G., Auschwitz-Birkenau Museum Suffers Wave of Abuse Following New Law, "Museums Association News", 14 May 2018, https://www.museumsassociation.org/ museums-journal/news/14052018-auschwitz-birkenau-wave-of-abuse [accessed: 10.09.2020].

Klauziński S., W polskiej pamięci o wojnie Auschwitz kilka razy ważniejsze niż Powstanie Warszawskie i Katyń [In the Polish Memory of the War Auschwitz Is Several Times More Important than the Warsaw Uprising and Katyn], "OkoPress", 17 January 2020, https://oko.press/w-polskiej-pamieci-o-wojnie-auschwitz-kilka-razy-wazniejsze-nizpowstanie-warszawskie-i-katyn/ [accessed: 10.09.2020].

Kucia M., Auschwitz jako fakt społeczny: historia, współczesność i świadomość społeczna [Auschwitz as a Social Fact: History, Modernity and Social Awareness], Universitas, Kraków 2005.

Kucia M., The Europeanization of Holocaust Memory in Eastern Europe, "East European Politics and Societies" 2016, Vol. 30.

Mandarano N., Musei e media digitali, Carocci Editore, Roma 2019.

Marshall A., To Protest Colonialism, He Takes Artifacts from Museums, "The New York Times", 21 September 2020, https://www.nytimes.com/2020/09/21/arts/design/france-museum-quai-branly.html [accessed: 10.10.2020].

Massara K., Environmental Activists Focus on Museums that Take Oil Money, "The New York Times", 9 October 2018, https://www.nytimes.com/2018/10/09/business/environmental-activists-take-on-oil-money.html [accessed: 20.09.2020].

Michlic J.B., 'At the Crossroads': Jedwabne and Polish Historiography of the Holocaust, "Dapim: Studies on the Holocaust" 2017, Vol. 31.

Mihr A., Cyber Justice. Human Rights and Good Governance for the Internet, Springer, Berlin 2017.

Mihr A., Why Holocaust Education is not Always Human Rights Education?, "Journal of Human Rights" 2015, Vol. 14

Palmer E., Holocaust Survivors are Repeatedly Asking Mark Zuckerberg to Ban Denial on Facebook, "Newsweek", 29 July 2020, https://www.newsweek.com/holocaust-denial-banned-facebook-survivors-1521039 [accessed: 20.09.2020].

Państwowe Muzeum Auschwitz-Birkenau, Fake newsy pojawiaja się także w obszarze Pamięci [Fake News Also Affect the Area of Memory], 10 June 2019, http://auschwitz. org/muzeum/aktualnosci/fake-newsy-pojawiaja-sie-takze-w-obszarze-pamieci,1965. html [accessed: 10.09.2020]

Pessach G., Shur-Ofry M., Copyright and the Holocaust, "Yale Journal of Law and the Humanities" 2018, Vol. 30.

Pietka B., Spory wokół liczby ofiar Auschwitz [Disputes over the Number of Auschwitz Victims], https://bohdanpietka.wordpress.com/2016/01/25/spory-wokol-liczby-ofiarauschwitz/ [accessed: 10.09.2020].

Piper F., Auschwitz. How Many Perished Jews, Poles, Gypsies..., Frap-Books, Oświęcim 1996. 
Randle A., We Were Tired of Asking: Why Open Letters Have Become Many Activists' Tool of Choice for Exposing Racism at Museums, "ArtNet News", 15 July 2020, https://news.artnet.com/art-world/museum-open-letters-activism-1894150 / [accessed: 20.09.2020].

Reynolds A., Circulation, Impact and the Use of Twitter in Contemporary Museum Activism, "Participations, Journal of Audience \& Reception Studies" 2020, Vol. 17.

Ross M., Interpreting the New Museology, "Museums and Society" 2004, Vol. 2.

Röttjer J., Safeguarding "Negative Historical Values" for the Future? Appropriating the Past in the UNESCO Cultural World Heritage Site Auschwitz-Birkenau, "Ab Imperio" 2015, Vol. 4.

Russo A. et al., Participatory Communication via Social Media, "Curator. The Museum Journal" 2008, Vol. 51.

Shaw A., Harris G., Art World Presses Pause for \#BlackOutTuesday, "The Art Newspaper", 2 June 2020, https://www.theartnewspaper.com/news/art-world-presses-pause-forblackouttuesday [accessed: 20.08.2020].

Smithsonian Institution, Office of the Inspector General, Use of Social Media: Report Number A-11-01,28September 2011,https://www.si.edu/Content/OIG/Audits/2011/A-11-01. pdf [accessed: 10.09.2020].

Smithsonian Institution, SITP Strategic Overview, 14 February 2011, https://soar.si.edu/sites/ default/files/reports/2015.sp.ocio.pdf [accessed: 20.09.2020].

Smithsonian Institution, Smithsonian Directive 609: Digital Asset Access and Use, 19 December 2019, https://www.si.edu/content/pdf/about/sd/SD609.pdf [accessed: 10.09.2020].

Smithsonian Institution, Smithsonian Directive 814: Management of Official Smithsonian Social Media Accounts, 27 June 2019, https://www.si.edu/content/pdf/about/sd/SD-814.pdf [accessed: 10.09.2020].

Smithsonian Institution, Strategic Plan: Fiscal Years 2010-2015. Inspiring Generations through Knowledge and Discovery, https://files.eric.ed.gov/fulltext/ED583517.pdf [accessed: 10.09.2020].

Smithsonian Institution, Strategic Plan: Smithsonian 2022, https://files.eric.ed.gov/fulltext/ ED583523.pdf [accessed: 10.09.2020].

Spilberger D., How the Auschwitz Memorial's Twitter Account Became the Internet's Holocaust's Fact Checker, "The Insider", 27 January 2020, https://www.insider.com/auschwitz-memorial-museum-twitter-internet-holocaust-fact-checker-paul-sawicki-2020-1 [accessed: 20.09.2020].

Spruce L., Leaf K., Social Media for Social Justice, "Journal of Museum Education" 2017, Vol. 42.

Stola D., Poland's Institute of National Remembrance: A Ministry of Memory?, in: M. Lipman, A. Miller (eds.), The Convulsions of Historical Politics, CEU Press, Budapest 2012.

The Holocaust, Anti-Semitism and Racism: European Parliament Resolution on Remembrance of the Holocaust, Anti-Semitism and Racism, OJ C 253E, 13.10.2005, p. 37.

UNESCO, OSCE, Addressing Anti-Semitism through Education. Guidelines for Policymakers, Paris-Warsaw 2018, https://unesdoc.unesco.org/ark:/48223/pf0000263702 [accessed: 20.09.2020].

United Nations General Assembly, Resolution 60/7: Holocaust Remembrance, 1 November 2005, A/RES/60/7, https://undocs.org/A/RES/60/7 [accessed: 24.10.2020].

United Nations General Assembly, Resolution 70/1: Transforming our World: the 2030 Agenda for Sustainable Development, 25 September 2015, A/RES/70/1, https://undocs.org/A/ RES/70/1 [accessed: 20.09.2020]. 


\section{GENERAL ARTICLES}

Ewa Manikowska

Ustawa z dnia 2 lipca 1947 r. o upamiętnieniu męczeństwa narodu polskiego i innych narodów w Oświęcimiu [Law of 2 July 1947 Regarding the Commemoration of Martyrdom of the Polish Nation and Other Nations in Oświęcim], Dz.U. 1947 No. 52 item 265.

Wellers G., Essai de détermination du nombre des morts au camp d'Auschwitz [An Attempt to Determine the Number of Victims of Auschwitz], "Le Monde Juif" 1983.

Wong A., Social Media Towards Social Change: Potential and Challenges for Museums, in: R. Sandell, E. Nightingale (eds.), Museums Equality and Social Justice, Routledge, London 2012.

Wong A.S., Ethical Issues of Social Media in Museums: A Case Study, "Museum Management and Curatorship" 2011, Vol. 26.

World Jewish Congress, Anti-Semitic Symbols and Holocaust Denial in Social Media Posts, January 2018, https://www.worldjewishcongress.org/download/3KVjYgi8FNOTxdWd5HeFPw?utm_source=PRESS\&utm_campaign=3d806f4ab8-EMAIL_CAMPAIGN_2018_02_08\&utm_medium =email\&utm_term=0_c3b21e69b1-3d806f4ab8\&utm_source $=$ WJC+Mailing+Lists\&utm_campaign=78bfed156d-EMAIL_CAMPAIGN_2018_02_08\&utm_medium =email\&utm_term=0_04292c525e-78bfed15 6d-318920277 [accessed: 20.09.2020].

Wóycicka Z., Arrested Mourning: Memory of the Nazi Camps in Poland 1944-1950, Peter Lang, Frankfurt am Mein 2013. 